\title{
“Na arca” de Machado de Assis: as relações entre suporte e produção de sentidoi
}

\author{
Luiza Helena Damiani Aguilar*
}

Resumo: Este artigo analisa os efeitos de sentido produzidos pelo conto "Na arca", de Machado de Assis, nos diferentes suportes de sua publicação: o periódico carioca $O$ cruzeiro em maio de 1878 e a coletânea de contos Papéis avulsos, organizada pelo autor em 1882. A presente investigação conferirá destaque ao conceito de mediação editorial, tendo em vista o pressuposto de examinar o modo por meio do qual os diferentes espaços de publicação de um escrito participam da significação por ele produzida.

Palavras-chave: Machado de Assis. Mediação editorial. O cruzeiro. Papéis avulsos.

Abstract: This article analyses the meanings produced by the short story "Na arca", written by Machado de Assis, when published in two different media: the newspaper O cruzeiro in May of 1878 and the collection of short stories Papéis avulsos, arranged by the author in 1882 . Therefore, the following study highlights the concept of discursive ambience and editorial mediation, in order to examine how the different spaces of literary publishing participate on the meanings of a text.

Keywords: Machado de Assis. Editorial mediation. O cruzeiro. Papéis avulsos.

Résumé : Cet article analyse les effets de signification que le conte « Na arca ", écrit par Machado de Assis, a produit dans deux différents médias : le journal O cruzeiro, en mai de 1878, et le livre Papéis avulsos, organisé par l'auteur en 1882. Alors, cette étude mettra en évidence le concept de l'ambiance discursive, avec lequel on a l'intention d'examiner comment les différents espaces de publication d'un texte peuvent participer de ses significations.

Mots-clés: Machado de Assis. Ambiance discursive. O cruzeiro. Papéis avulsos.

\section{Introdução}

\footnotetext{
${ }^{\mathrm{i}} \mathrm{O}$ artigo em questão é resultado de duas pesquisas: a de Iniciação Científica intitulada "Machado de Assis em jornal e em livro: os diferentes suportes e os diferentes sentidos do conto 'Na arca'" (2016), desenvolvida com auxílio de uma bolsa Fapesp; e a de mestrado intitulada "Machado de Assis em jornal e livro: diferentes suportes e sentidos dos três contos de Papéis Avulsos publicados antes de Memórias Póstumas de Brás Cubas", com bolsa pela CNPq.

" Mestranda em Estudos Comparados de Literaturas de Língua Portuguesa pela Faculdade de Filosofia, Letras e Ciências Humanas da Universidade de São Paulo. http://orcid.org/0000-0003-3013-1223
}

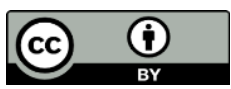


Os sentidos de um texto muito têm a dever aos meios de publicação em que o escrito veio a público. Qual é a linha editorial do periódico que o estampou? Qual a especificidade e a localização espacial da seção do jornal que o acolheu? Que importância tem a casa editorial que o abrigou em forma de livro? Qual a especificidade da edição princeps em questão? Como ela se apresenta e distribui suas matérias? Quais critérios, considerando-se a maior perenidade do suporte livresco, orientaram a seleção dos conteúdos por parte do autor? Qual o peso que quem assinou a obra possui e qual o impacto de tal assinatura na leitura do livro em questão? Como contribuem os paratextos presentes na obra para os sentidos que dela podem ser extraídos?

Roger Chartier, um dos maiores teóricos da história do livro e da importância do suporte enquanto elemento produtor de sentido, comenta em seu Os desafios da escrita:

\begin{abstract}
A questão essencial que, na minha opinião, deve ser colocada por qualquer história do livro, da edição e da leitura é a do processo pelo qual os diferentes atores envolvidos com a publicação dão sentido aos textos que transmitem, imprimem e leem. Os textos não existem fora dos suportes materiais (sejam eles quais forem) de que são os veículos. Contra a abstração dos textos, é preciso lembrar que as formas que permitem sua leitura, sua audição ou sua visão participam profundamente da construção de seus significados. O "mesmo" texto, fixado em letras, não é o "mesmo" caso mudem os dispositivos de sua escrita e de sua comunicação (CHARTIER, 2002, p. 61-62).
\end{abstract}

A publicação de textos em periódicos era, no século XIX, uma das principais formas de divulgação literária. Sendo assim, faz-se importante analisar, a partir desse ponto de vista explicitado por Chartier, quais foram os sentidos que os dispositivos de leitura de um jornal e de um livro foram capazes de emprestar para a obra de Machado de Assis, um dos maiores autores de língua portuguesa.

Publicado em 1878 no jornal O cruzeiro, o conto "Na arca" praticamente não sofreu alterações textuais da versão original para a que posteriormente saiu na coletânea Papéis Avulsos, diferentemente do que ocorreu com seus dois irmãos da coletânea que também foram impressos durante a década de 1870: "Uma visita de Alcebíades", publicado em 1876 no Jornal das famílias e "A chinela turca”, publicado em 1875 em $A$ epocha. Em "Na arca", exceto pelo texto introdutório, que foi eliminado, as mudanças 
foram muito sutis, provocando pouca ou nenhuma diferença no sentido quando se considera tão-somente a textualidade ${ }^{1}$.

Sendo assim, quais são os protocolos de leitura que o periódico e o livro emprestam para um conto cuja estrutura principal quase não se alterou? Livro esse que foi enquadrado pela crítica contemporânea ao autor, como representante da "segunda maneira” de Machado de Assis, da qual Memórias póstumas de Brás Cubas, publicado cerca de dois anos mais tarde na Revista brasileira e depois em 1881 pela Typographia Nacional, seria o marco inicial para os resenhistas contemporâneos a Machado.

"Na arca”, primeiro texto escrito antes de 1880 incluso quase na íntegra em uma coletânea posterior a essa data, foi, de certa maneira, o texto inaugural de um projeto ficcional machadiano que teria mais expressão dali em diante. "A chinela turca" e "Uma visita de Alcebíades", apesar de serem anteriores a "Na arca", foram bastante alterados de suas versões iniciais que saíram em periódicos para o produto "final" em Papéis avulsos, especialmente o segundo. "Na arca”, porém, permanece quase incólume em sua estrutura textual de um suporte a outro, o que nos leva a crer que o próprio autor pudesse vislumbrar neste conto os traços que desejava imprimir em sua escrita ou ainda daquilo que alguns críticos vieram a chamar de "segunda fase".

\section{"Na arca" - o texto em si}

Escrito em chave parodística e com o subtítulo "três capítulos inéditos do Gênesis", "Na arca" é organizado em versículos, numa estrutura oracional, linguística e de estilo muito similar à da Bíblia - muito embora sejam feitas algumas atualizações lexicais justificadas pela introdução suprimida em livro. Nesse proêmio de tom jornalístico, Eleazar - o pseudônimo de origem bíblica que assina o texto - afirma ser

\footnotetext{
${ }^{1} \mathrm{O}$ procedimento de modificar o texto de acordo com o suporte em que publica o texto não ficou restrito aos primeiros anos da vida literária do autor. Ana Cláudia Suriani, em Machado de Assis: do folhetim ao livro, estuda as alterações que Machado mobiliza entre a versão de Quincas Borba publicada em jornal e a que depois saiu em livro.
} 
mero tradutor de capítulos inéditos do livro sagrado enviados por um capuchinho de Jerusalém: “o manuscrito foi achado nos alicerces da casa de Caifás" (ASSIS, 1878, p. 1), segundo o pretenso tradutor. Eleazar acredita que o texto seja um complemento perdido do Gênesis, enquanto o capuchino afirma tratar-se de uma interpolação. A introdução do conto, portanto, é uma grande brincadeira com o conceito de autenticidade textual. Ao inserir um "trecho inédito" na Bíblia e afirmar veementemente que se trata de um manuscrito perdido do original, Machado torna, ao mesmo tempo, sua "tradução" mais verídica e o livro sagrado mais ficcional. "Na arca” é verossímil no universo em que se encaixa, mas sem perder o tom literário de sátira.

O narrador, aparentemente alheio, é onisciente neutro e narra a partir de uma visão de fora da história, limitando-se a descrever o que acontece à sua volta sem um conhecimento aprofundado dos personagens e seus sentimentos, ausente também de comentários mais autorais, algo que aparece com frequência em Memórias póstumas e Quincas Borba (1891), por exemplo. Suas intervenções são breves e mais diretas, frequentemente restringindo-se ao intermédio de diálogos, como em "11. — Mas dizendo Sem: - 'Acho pouco duzentos côvados' - , retorquiu Jafé: 'Pois sejam quinhentos cada um (...)" (ASSIS, 1882, p. 129).

Escorando os elementos temporais e espaciais do texto no estilo da obra parodiada - ordem cronológica dos fatos e poucos elementos de ambientação -, é principalmente por meio do discurso dos personagens que Machado toma liberdade para aplicar o conceito de paródia de modo mais intenso, estilizando o texto à sua maneira, tornando-o mais humorístico e irônico. A ambição desmedida de Sem e de Jafé é responsável por uma planificação dos personagens, que passam a ser vistos à luz dessa única característica predominante, como caricaturas. Ela também é o principal elemento causador do efeito moralizante presente no texto, seja ele visto a partir de um escopo mais católico como no jornal, seja a partir da moral mais aberta e plural constitutiva da sátira menipeia, tradição cujos elementos aparecem nesse e em outros textos de Papéis avulsos.

Mais interessante ainda é observar os personagens à luz de dois fatores: a guerra russo-turca de 1877 a 1878, em consonância com a divisão de terras entre os três herdeiros no décimo capítulo do Gênesis; e o que acontece com os filhos de Noé no nono 
capítulo do primeiro livro do Pentateuco, que é posterior aos acontecimentos do conto e será descrito a seguir.

Em primeiro lugar, Noé, desapontado com seus filhos, queixa-se de que "26. 'Eles ainda não possuem a terra e já estão brigando por causa dos limites. O que será quando vierem a Turquia e a Rússia?"” (ASSIS, 1882, p. 138). Levando-se em consideração que, na partilha de terras como relatada na Bíblia, Jafé ocupa uma região mais próxima ao leste europeu e Sem dirige-se à Ásia, os dois personagens poderiam ser interpretados como alegóricos, representantes desses dois países e de sua guerra por disputa de território. Curiosamente, essas duas nações que se encontravam em guerra possuem terras nos dois continentes, ou seja, ambos são países euroasiáticos. Nesse sentido, Noé - e, consequentemente, o episódio relatado no conto - também poderia apresentar um caráter profético ao mencionar a guerra, algo que aparece com frequência na Bíblia: o conflito que ocorre entre Sem e Jafé por terras repetir-se-ia nos anos vindouros com a Rússia e a Turquia. Dessa forma, a fala de Noé aproxima o leitor de uma profecia com caráter bíblico, mesmo que parodístico.

Paralelamente a isso, Cam, no texto das Escrituras, é quem fica com territórios correspondentes ao sul do Monte Ararate - região mais próxima do norte da África. Posteriormente, ele também é amaldiçoado por seu pai quando o vê nu e comete a indiscrição de partilhar o fato com seus irmãos. Ao longo do conto, porém, Cam é o mais moderado e menos ambicioso dentre os três descendentes, tentando apartar a briga e sendo ignorado ou até mesmo ridicularizado por seus irmãos.

\section{O conto no contexto do jornal $O$ cruzeiro}

A publicação de "Na arca" no jornal O cruzeiro é um dado interessante que pode indicar que o próprio Machado viu no texto uma "nova maneira” em sua escrita. Quase toda a produção de Machado para o jornal, à exceção de Iaiá Garcia, é assinada pelo pseudônimo Eleazar e vem carregada de um ar de "obra de experimentação". Machado teria utilizado o espaço do rés do chão do jornal para testar novos modos de escrita, 
flertando com elementos de paródia, humor e do fantástico, não só em "Na arca”, mas em alguns textos que o autor escolheu não incluir em futuras publicações em livro, como “Filosofia de um par de botas”, "Um cão de lata ao rabo" e "Elogio da vaidade”.

Surgido entre o final do século XVIII e início do século XIX, em diferentes países da Europa - na Itália como terza pagina e na França como le feuilleton, por exemplo -, o espaço jornalístico conhecido como "folhetim” designava o rodapé (rés do chão), geralmente da primeira página, dos periódicos. Na medida em que vai se especificando como um lugar destinado, sobretudo, ao entretenimento no interior das folhas, ele passa a abarcar desde crônicas e resumos dos acontecimentos da semana até romances seriados e críticas literárias.

No rés do chão dos jornais brasileiros, eram publicados diferentes tipos e gêneros de texto: os romances em formato de "folhetim”, ou seja, calcados na fórmula do “continua amanhã” e na demanda do público; os romances comuns publicados de maneira seriada, situação na qual o espaço funcionava como incentivo à impressão e à divulgação de obras de diferentes autores; as críticas literárias, teatrais e textos sobre cultura de modo geral; literatura de diferentes gêneros, como contos, fantasias e poesia; e, por fim, o gênero intitulado propriamente como "folhetim", pai daquilo que hoje chamamos de crônica, em que o autor comentava os fatos da semana em linguagem mais próxima da literatura do que do jornalismo.

Em tal contexto, a cultura letrada e a imprensa brasileiras, sob forte ascendência europeia, adotaram o folhetim em grande escala, tanto como espaço de publicação quanto como gênero textual, seja com escritos curtos informativos ou com romances seriados. Assim, como estratégia para ampliar a circulação e a vendagem, vários de nossos jornais começaram a destinar o rodapé de suas primeiras páginas à publicação de textos que fugissem da seriedade que, em tese, deveria predominar em suas outras partes e seções. Nesse movimento, muitos periódicos contavam com traduções de romances folhetinescos franceses, de autores como Alexandre Dumas, Eugène Sue e Charles Rabou, ou com colaborações de autores nacionais que consolidavam seus nomes no cenário literário do Brasil oitocentista: José de Alencar, Joaquim Manuel de Macedo e Machado de Assis são apenas alguns exemplos. 
Não por acaso, no século XIX, alguns de nossos maiores jornais, como o Correio mercantil, o Jornal do commercio e a Gazeta de notícias, esse último o periódico de maior circulação da época, contavam com uma seção de rodapé destinada a produções literárias e aos sucessos da semana ${ }^{2}$. Não seria diferente n'O cruzeiro, que apresentou o espaço desde seu número inaugural, com a publicação primeira de Iaiá Garcia.

Pouco depois do final da publicação do romance, Machado, agora sob a identidade de Eleazar, assumiu uma espécie de coluna às terças-feiras, na qual publicava majoritariamente textos de ficção mais variados: cinco fantasias, dois contos, um diálogo em verso e uma vária3 . O conjunto de textos publicados pelo autor no periódico é considerado de difícil classificação, como assinalam John Gledson e Lúcia Granja:

\begin{abstract}
Pouco conhecido e, acima de tudo, raramente considerado em conjunto, ele sofreu, como talvez nenhuma outra série de textos, com a história caótica da edição das 'Obras completas' de Machado. A explicação clara para isso é que ninguém sabia como classificá-lo (...) O que os vincula? Provisoriamente, podemos dizer que eles são parte do seu esforço criativo, que atravessava então um período de crise - o mais importante de sua vida, sem dúvida. (...) Só o fato de esses textos serem, por vezes, experimentais e zombarem de classificações genéricas devia ter despertado mais interesse do que despertou (GLEDSON \& GRANJA, 2008, p. 14-15).
\end{abstract}

Até hoje, os textos publicados no jornal sofrem com isso: dois deles, por exemplo, sequer constam na edição mais recente da Obra completa, publicada pela Nova Aguilar em 2015. A classificação em gênero da enorme maioria desses textos também é bastante questionada: escritos muito parecidos, como "Antes da missa" e "O bote de rapé" recebem classificações distintas, como apontam Gledson e Granja (2008, p. 15).

Outro fator que traz elementos interessantes para a análise da experimentação realizada por Machado nos textos publicados n'O cruzeiro manifesta-se nos posicionamentos do periódico e de seus colegas de redação. Os colunistas do jornal incluindo o próprio Machado, em suas famosas resenhas que formam o compêndio

\footnotetext{
${ }^{2}$ Neste caso, quando eram publicados textos curtos com um "resumo" da semana, a seção costumava chamar-se "variedades", como aponta Meyer (1985).

${ }^{3}$ Esses textos, em ordem de publicação, são: "O bote de rapé", "A sonâmbula", "Um cão de lata ao rabo", "O califa de platina", "Filosofia de um par de botas", "Antes da missa", "Na arca, "O caso Ferrari" e "Elogio da vaidade".
} 
"Literatura realista: O primo Basílio, romance do Sr. Eça de Queiroz, Porto, 1878"4 fizeram diversas críticas ao realismo determinista de escritores como Eça de Queiroz. Enquanto muitos dos colunistas do jornal adotam posturas de crítica moral ao livro, classificando o realismo como uma escola torpe de "lama e pus, podridão e matéria" (EGO, 1878, p.3), Machado vai além. O Bruxo do Cosme Velho desaprova, também, os preceitos estilísticos do realismo, comentando que "a nova poética (...) só chegará à perfeição no dia em que nos disser o número exato dos fios de que se compõe um lenço de cambraia ou um esfregão de cozinha” (ASSIS, 2015, p. 1207). Além disso, ele reprova a construção das personagens em O primo Basílio, especialmente de Luísa, por quem protesta pela ausência de paixões, remorsos e consciência: "a Luísa - força é dizê-lo -, a Luísa é um caráter negativo, e no meio da ação ideada pelo autor, é antes um títere do que uma pessoa moral" (ASSIS, 2015, p. 1207).

O cruzeiro era, então, um ambiente propício para que Machado, em busca de rumos que fossem além do Romantismo, já menos valorizado no período em questão, pudesse experimentar em sua literatura sem caminhar pelos trilhos da escola Realista, vigentes na época e aclamados por outras folhas, que zombavam de Iaiá Garcia, comparando-o com os romances do autor português e jogando luz negativa na narrativa do Bruxo do Cosme Velho quando comparada com a do realismo. O pesquisador Jaison Crestani levanta a hipótese de que os textos críticos do escritor, em relação ao Primo Basílio, seriam uma reação de Machado às incessantes críticas feitas por outros jornais à Iaiá Garcia e ao seu estilo (CRESTANI, 2013)5.

Além disso, ao longo de 1878, primeiro ano da folha e único no qual o autor de Papéis avulsos colaborou, há diversos indícios do viés católico adotado pelo jornal: o repúdio àquilo que chamavam de "basilismo", uma seção com o nome de "Atos religiosos", que convida a população para celebrações, missas e eventos em igrejas da cidade ou divulga obituários e, até mesmo detalhes mais sutis, como uso de marcações itálicas em certos termos como "diabos" ou uma visão pejorativa de outras religiões, como um tom desfavorável empregado em notícias referentes à capoeira, por exemplo.

\footnotetext{
${ }^{4}$ As críticas foram publicadas por Machado em 16 e 30 de abril de 1878.

${ }^{5}$ Nesse artigo, o pesquisador estuda não só a recepção do romance pelo público e pelo meio jornalístico como também o modo como o romance integra o perfil editorial do periódico.
} 
No jornal, portanto, "Na arca" pode adquirir um sentido que vai ao encontro do moralismo religioso: brincando com a narrativa bíblica, o texto poderia ter, para os leitores, um viés de crítica cristão-moralista à ganância, embasado pela assinatura de Eleazar, um "tradutor" com nome bíblico. Ao contrário de escritores realistas, como Eça de Queirós, muito criticados pelo jornal a partir de um viés moral da leitura de $O$ primo Basílio, Machado contribuiria com textos nos quais os personagens que seguem uma conduta moral inapropriada seriam submetidos a uma espécie de julgamento.

Além disso, a referência, presente no conto, à guerra russo-turca de 1878 adquire um caráter circunstancial e particular: ela serve como elemento de conexão entre os personagens do texto - Sem, Jafé, Cam e Noé, pertencentes ao Velho Testamento - e os leitores da época, que liam notícias sobre o conflito no próprio $O$ cruzeiro. O conto dialoga com os sucessos da semana, que frequentemente constituíam os textos pertencente ao gênero chamado de "folhetim", pertinente à seção em que "Na Arca" foi publicado. Embora não se tratasse de um texto de "variedades", o conto conversava com as notícias e o contexto histórico da época. Narrador e leitor, nesse caso, estão mais próximos da materialidade dos fatos, e a guerra russo-turca é uma realidade mais imediata, partilhada por ambos na época da publicação do conto em jornal.

Cabe ainda mencionar que a introdução presente na versão jornalística, excluída posteriormente na coletânea, parece o anúncio de um grande furo jornalístico: embora o capuchino peça ineditismo, Eleazar conta ao leitor que "não p[ô]de resistir à tentação de a publicar, e o f[az] sem remorso, porque um achado desta ordem não tolera larga obscuridade" (ASSIS, 1878, p. 1). Quando Eleazar propõe escrever uma tese de seiscentas páginas para comprovar que os três capítulos não se tratam de mera interpolação, ele parece, por meio de uma blague, querer convencer aquele leitor de jornal, acostumado a ler notícias e fatos, de que o excerto ali publicado não é apenas literário.

Por fim, retomando Chartier, o ser humano guarda seus textos com o objetivo de preservar do esquecimento "os traços do passado, a lembrança dos mortos ou a glória dos vivos" (2007, p. 9). No entanto, o apagamento de certos textos seria necessário para não provocar uma proliferação sem controle. Ao eleger, entre seus escritos avulsos estampados em $\mathrm{O}$ cruzeiro, apenas “Na arca” para figurar em livro, Machado fez uma escolha quanto ao que deveria ser "esquecido", a partir do momento em que os leitores 
descartassem as folhas dos jornais, e o que deveria permanecer para a posteridade, em volume.

\section{O conto dentre seus irmãos em Papéis avulsos}

Em meio aos outros contos de Papéis avulsos, "Na arca" adquire caráter mais permanente, distante da natureza mais "descartável” do jornal. Ele e seus demais irmãos sentados à mesma mesa são capazes de emprestar significados uns aos outros, e estabelecer um conjunto. Além disso, o suporte livro oferece ao conto uma atmosfera muito mais permanente, em termos históricos, do que a de $O$ cruzeiro, fazendo com que certas perspectivas se alterem. O conto passa a fazer parte, então, de uma obra que seguramente foi responsável por consolidar aquilo que seria chamado de "segunda maneira" do estilo machadiano tanto para a crítica da época quanto para muito daquilo que será dito sobre ele ao longo do século XX.

Papéis avulsos é publicado em 26 de outubro de 1882, dois anos após a impressão primeira de Memórias póstumas de Brás Cubas na Revista brasileira. A coletânea é composta por um total de doze escritos: "O alienista”, “Teoria do medalhão”, "A chinela turca”, "Na arca”, “D. Benedita”, “O segredo do bonzo”, “O anel de Polícrates”, “O empréstimo”, “A sereníssima república”, “O espelho”, “Uma visita de Alcebíades” e "Verba testamentária". Dentre eles, contos como "Uma visita de Alcebíades" e "A sereníssima república” têm uma verossimilhança construída a partir de elementos fantásticos, enquanto "Teoria do medalhão" e "O empréstimo", por exemplo, escoramse na possível veracidade do que contam. Já textos como "A chinela turca" e "O espelho" transitam entre essas duas vertentes, trabalhando a fantasia de maneira sutil.

A advertência da obra merece muita atenção. Nela, Machado comenta o título da obra, apontando que embora os textos sejam "avulsos", eles não estariam de todo desconectados, como "pessoas de uma só família, que a obrigação do pai fez sentar à mesma mesa" (ASSIS, 1882, p. I). É também nesse trecho que Machado coloca em foco a questão da unidade da obra. Essa unidade, segundo Ivan Teixeira (2005), precisa ser de 
conceito e não de ação, já que o artista procura agrupar uma série de narrativas curtas que condensam pedaços dispersos de acontecimentos. Curiosamente, os dois livros de contos publicados por Machado, antes de Papéis avulsos, possuíam elementos unificadores nos próprios títulos das obras (Contos fluminenses, Histórias da meianoite). Nas coletâneas publicadas a partir da década de 1880, porém, os títulos são, em sua maioria, mais dispersos (Várias histórias, Páginas recolhidas) ou até mesmo mais enganosos, como em Histórias sem data.

Logo a seguir, ainda na Advertência, o autor aborda um dos elementos mais importantes que favorecia a coesão entre os textos, que é a questão do gênero. Parte dos contos do livro envolve paródias de outras formas textuais, brincando com os limites de cada uma delas. Sobre isso, Teixeira afirma que:

(...) o segundo parágrafo introduz a questão do gênero literário em Papéis avulsos, deixando claro que seus escritos não se ajustam à prática costumeira da narrativa curta. Se há textos que, sem o ser, podem passar por contos tradicionais, haverá também páginas que transcendem a forma usual do gênero. O leitor da primeira espécie não se identificará talvez com o da segunda, embora possa haver ligeira relação entre ambos. Por essa razão, a advertência se esforça por captar a atenção dos dois, convertendo-os igualmente à poética da forma livre. Se o cinismo da voz satírica unifica a pluralidade de situações encenadas em Papéis avulsos, poder-se-ia dizer que os contos se aproximam, também, pelo repúdio ao óbvio e pelo amor à convenção, entendidos - o amor e o repúdio - como a sugestão de anarquia por meio do uso imprevisto da norma. De fato, um dos predicados importantes da poética libertina será talvez a suspensão da espontaneidade e o apego despistado ao artifício (TEIXEIRA, 2010, p. 147-148).

Cada conto da coletânea possui uma forma diferente e poderia, por sua vez, ser classificado em um gênero diferente. "O alienista” teria como base as supostas crônicas de Itaguaí, simulando funcionar como documento histórico. “Teoria do medalhão” revela-se um diálogo paródico com O príncipe, de Maquiavel. “A chinela turca” opera em um ambiente onírico, contando mais de uma história simultaneamente. "Na arca" se mostra um pastiche da Bíblia, cujo subtítulo, em chave joco-séria, assinala: "três capítulos inéditos do Gênesis". O retrato de "D. Benedita”, conto que mais aproxima-se de narrativas convencionais, faz uma incursão pela fantasia ao final. "O segredo do bonzo" é também pastiche, mas, agora, do livro Peregrinações, do escritor quinhentista Fernão Mendes Pinto, portando também um subtítulo indicador de capítulos inéditos. 
"O anel de Polícrates", mais uma produção que se vale da forma de diálogo, parodia, em ordem inversa, o mito de Polícrates. "O empréstimo" é "anedota filosófica", como dizia o próprio subtítulo do conto quando publicado na Gazeta (SILVA, 2009, p. 8). "A sereníssima república” é conferência científica do cônego Vargas e, ao mesmo tempo, retrato das alternativas eleitorais do Brasil na época. “O espelho” é "esboço de uma nova teoria sobre a alma humana", como diz o próprio subtítulo, adquirindo também um sentido filosófico. "Uma visita de Alcebíades" assemelha-se a uma carta que relata um assunto aparentemente sério e capaz de perturbar o remetente. "Verba testamentária" apresenta-se como um “caso patológico dedicado à Escola de Medicina”, conforme dizia seu subtítulo que também foi suprimido na versão do livro (SILVA, 2009, p. 9). Ivan Teixeira comenta essa peculiaridade:

E aqui ressurge questão importante para a apreensão da natureza menipeia dos contos de Papéis Avulsos: seus textos, sem deixar de serem contos, raramente se apresentam sob essa forma de narrativa. Possuem, ao contrário, estatuto ontológico de outra coisa, o que lhes confere a condição de sugerirem que o mundo da narrativa deve espelhar modos de produção de sentido alheios a ela própria (...) (TEIXEIRA, 2005, p. LII).

A dificuldade na delimitação de gênero não só é um dos maiores elementos de unidade no livro, como também é um dos pontos principais do gênero conhecido como sátira menipeia. Para Márlio Barcellos Pereira da Silva (2009), todos os contos da obra possuem elementos de paródia, dentre os quais ele destaca quatro: "Uma visita de Alcebíades”, “A sereníssima república”, “Teoria do medalhão” e "O anel de Polícrates”. Além desses, "O alienista”, "Na arca” e "O segredo do bonzo" também são casos em que os componentes de imitação joco-séria de algum outro gênero literário aparecem de forma mais clara.

A paródia, a mistura de gêneros e a mescla entre o cômico e o grave não são as únicas características da sátira menipeia que aparecem nos contos da coletânea. Machado trabalha muito com elementos do fantástico ao longo da obra, seja de forma mais clara, seja de modo mais sutil. "O segredo do bonzo", "A sereníssima república” e “Uma visita de Alcebíades” estão repletos desses elementos, tornando plausíveis algumas narrativas nada próximas do real. Isso aparece de maneira mais sutil em "O alienista", 
"A chinela turca", "Na arca", "O espelho" e mesmo em "Verba testamentária”, escritos cujos componentes fantásticos estão mais afastados do absurdo, tornando-os mais próximos da realidade do leitor.

A partir de detalhes como esse, é possível notar que a sátira menipeia tem papel importante na coesão entre os textos presentes na obra. Para Ivan Teixeira,

No primeiro parágrafo da advertência, a voz conceitual reivindica unidade para o volume. Em que consiste a unidade pretendida? O efeito de dispersão de elementos avulsos coloca-se como um dos propósitos do livro, que, com a diversidade de seu corpo extravagante, procura produzir sensação do desvario da existência. Pode-se dizer que os diferentes artefatos textuais (contos) do livro se unificam por uma espécie de retomada da tópica camoniana do desconcerto do mundo, em que os homens, contrariando qualquer lógica ideal, operam por uma prática avessa à razão. Assim, a adoção da sátira menipeia, sendo o elemento maior de coesão do volume, pode ser também interpretada como índice de uma espécie de anseio por um concerto jamais atingido. Isso acaba produzindo harmonia entre as partes da obra, que, mesmo na dispersão, deveria organizar-se segundo um princípio mínimo de coerência. Nada disso parece estranho ao gênero menipeu, cuja inverossimilhança estrutural será sempre aparente, porque a mistura e o absurdo integram o perfil de suas regras (TEIXEIRA, 2010, p. 147).

Ao comentar a sátira menipeia em Papéis avulsos, Ivan Teixeira aborda parcialmente o aspecto do conteúdo dos textos, desse "desconcerto do mundo" que leva os homens a agirem segundo uma lógica que não obedece aos preceitos típicos. Esse elemento é também de suma importância para o todo da obra, já que Machado, ao escrever parte dos contos da coletânea, opera em um estilo que confere verossimilhança a contextos aparentemente despropositados e dá caráter de documento histórico para situações irreais, ou no mínimo improváveis.

Para o estudioso Enylton de Sá Rego (1989), autor de O calundu e a panaceia, os textos da fase madura pertenceriam ao gênero conhecido como "sátira menipeia", e é por isso que alguns de seus escritos são de difícil classificação. Essa associação de Machado à sátira grega surgiu em José Guilherme Merquior, que aproximou a poética da forma livre de Brás Cubas com o gênero cômico fantástico da literatura menipeia.

Segundo Rego (1989), escritores como Sterne, Fielding, Xavier de Maistre, Stendhal e Erasmo de Roterdã, que fizeram parte da formação literária de Machado, também teriam bebido na fonte da tradição de Luciano de Samósata, o principal 
responsável pela difusão da sátira grega. Além disso, o escritor próprio Luciano, como fica claro na recomendação que o pai faz a Janjão em “Teoria do medalhão” para evitar “a ironia, esse movimento de canto de boca, cheio de mistérios, inventado por algum grego da decadência, contraído por Luciano, transmitido a Swift e Voltaire, feição própria dos céticos e desabusados" (ASSIS, 1882, p. 105-106)

Já a estética fragmentária da obra de Machado seria uma herança dos humoristas ingleses, como coloca Eugênio Gomes (1976). Uma das associações mais comumente feitas entre esses escritores e o brasileiro manifesta-se nos pontos de contato entre Memórias póstumas e A vida e as opiniões do cavalheiro Tristram Shandy (1759-1767), de Sterne (ROUANET, 2007).

Essa associação era comum desde a publicação inicial de Memórias póstumas em 1880, quando Artur Barreiros, conforme aponta Hélio de Seixas Guimarães (2017), sugere que o romance era inspirado diretamente pelos humoristas ingleses, comentário que pode ter resultado no prólogo "Ao Leitor", publicado apenas na edição em livro, de 1881 (GUIMARÃES, 2017, p. 45-46). Inclusive, Silvio Romero, notório detrator de Machado, trabalha essa relação com os romancistas do século XVIII, usando-a em desfavor do Bruxo, chamando-o de "macaqueador de Sterne" (GUIMARÃES, 2017, p. 45).

Esses irmãos que a obrigação do pai fez sentar à mesma mesa teriam como principais elementos de coesão, a partir dos pontos de vista apresentados, a tradição luciânica e a fragmentação da escrita herdada dos humoristas do século XVIII. A sátira grega lida com uma mistura entre o sério e o cômico, coloca em cena uma verdade moral que não é única e incontestável. Nesse sentido, embora ela tenha por objetivo a ideia do riso como elemento destruidor de falsos valores, assim como a sátira romana, sua moral não é absoluta, universal ou inquestionável.

Luciano ficou conhecido por escrever textos que mesclavam dois gêneros gregos muito distintos entre si: a comédia e o diálogo. Sendo o diálogo um gênero mais filosófico e, por sua vez, elevado, quando mesclado com a comédia, um gênero baixo, produz-se, sem dúvida, um efeito joco-sério. Outro aspecto importante da tradição luciânica é a inclusão da paródia como componente chave dos textos, seja de forma literal ou não. A paródia nada mais seria do que um “canto paralelo" e, segundo Enylton de Sá Rego, divide-se em três diferentes tipos: 
a) paródia aos gêneros e convenções da literatura passada e presente; b) paródia aos temas e ideias da literatura e da vida social contemporânea; c) paródia a textos definidos, através de citações literais ou quase-literais, geralmente em um contexto distinto daquele do qual a passagem em questão teria sido apropriada (REGO, 1989, p. 52).

A imaginação e a fantasia também são aspectos importantes na tradição luciânica. O escritor tomava liberdades com relação à veracidade histórica e ao suposto realismo presentes em suas produções, tendo sido responsável pelo primeiro texto literário sobre uma viagem à lua, por exemplo. Esse traço aparece também em Machado que, ao longo de seus contos, proporciona uma abordagem histórica para textos de cunho fantasioso, o que acaba por trazer o extravagante para o cotidiano.

Por fim, outra importante característica da tradição luciânica é a inversão da ordem natural das coisas. Essa inversão provoca um deslocamento a partir do qual a arte precisa se adaptar, criando novas formas de representar essa "nova ordem". Os textos que pertencem à tradição luciânica, portanto, não imitam a vida, a natureza, mas sim os discursos existentes. Para produzir uma imagem diferente do mundo (como Machado procura fazer em textos como "O alienista" ou Memórias póstumas de Brás Cubas), é preciso trabalhar com alegorias, cinismo e ironia para naturalizar o avesso, com o efeito de negar e, ao mesmo tempo, tornar ambíguo.

Nesse sentido, as críticas à ganância e à mesquinhez presentes em "Na arca” agora deixam de apresentar faceta de tom mais religioso, encaixando-se melhor no moralismo plural e relativo (em que o ponto de vista cria o objeto) da tradição luciânica. Na sátira menipeia, gênero em que os textos trabalham com uma mistura entre sério e cômico, a moralidade não é rígida e única como seria a visão católica d'O cruzeiro. Dessa maneira, a ganância e a mesquinhez são agora colocadas em xeque como comportamentos humanos questionáveis. Em conformidade com tal orientação, pode-se observar que os contos de Papéis avulsos, de modo geral, centram-se na análise e na problematização de diversos traços da natureza humana.

A coletânea veio a público, segundo os registros, com o selo de editora da Lombaerts \& Cia, editora do belga Jean Baptiste Lombaerts e seu filho Henri Gustave. Era de responsabilidade deles a publicação da revista $A$ estação, na qual saíram dois dos 
textos da coletânea ("O alienista” e "D. Benedita”) e na qual Machado de Assis teria colaborado também como coordenador ou editor literário ${ }^{6}$. No entanto, tanto a Gazeta de notícias quanto a Revista illustrada, nas resenhas que publicam sobre a obra, atribuem a edição à casa ou ao senhor Garnier, sem qualquer menção à Lombaerts \& Cia. Na crítica publicada em francês pelo Jornal do commercio, porém, constam menções às duas editoras: Garnier teria editado a obra, ficando a impressão a cargo da Lombaerts.

Poucas foram as obras verdadeiramente editadas pelos belgas. De acordo com Laurence Hallewell (2012), em seu estudo sobre o livro no Brasil, a Lombaerts realizou muitos trabalhos de impressão por encomenda. Dentre eles, o estudioso inglês elenca duas outras produções de Machado que foram encomendadas para a Lombaerts por Garnier: Histórias sem data (1884) e Quincas Borba (1991) (HALLEWELL, 2012).

A partir desses dados, é possível estabelecer a hipótese de que, assim como os dois livros mencionados, Papéis avulsos também foi editado por Baptiste Louis Garnier e impresso pela Lombaerts, sob encomenda. É estranho, porém, que não seja feita qualquer menção à casa Garnier na primeira edição da coletânea, sendo que em Quincas Borba, por exemplo, consta o nome do francês na folha de rosto da obra. A confusão também pode ser associada ao fato de Machado de Assis ter sido o primeiro escritor nacional a ter, na figura de Garnier, um editor que o acompanhou ao longo de toda a sua obra.

Garnier foi um dos grandes incentivadores da literatura nacional. Além de editar coleções inteiras de alguns dos autores mais rentáveis da época, como José de Alencar e Bernardo Guimarães, Garnier sabia reconhecer talentos como o de Machado e apoiá-los, mesmo que o Bruxo não tivesse a preocupação em aderir a uma forma de escrita fácil para o agrado do público. O crítico reproduzido pelo Jornal do Commercio também comenta que a Lombaerts teria sido responsável por uma "execução tipográfica cuidadosa" de Papéis avulsos, digna do autor e do editor, não deixando a desejar em relação à reputação de Garnier como editor no país.

O livro também soma à leitura do conto a assinatura do autor, sem o intermédio de um pseudônimo, ao contrário do que acontecera na publicação n’O cruzeiro. O nome

\footnotetext{
${ }^{6}$ Essa hipótese é amplamente estudada no terceiro capítulo da obra $O$ altar e o trono, de Ivan Teixeira.
} 
Machado de Assis é um fator que empresta importante sentido ao conto. O Bruxo do Cosme Velho era um dos autores mais consagrados de nossa literatura já na época da publicação da obra, e adquirira, após a publicação de Memórias póstumas de Brás Cubas, a pecha de filósofo, e de autor que misturava o humour inglês com o pessimismo nas críticas de suas obras publicadas pelas folhas da época. Nesse sentido, em se tratando de uma continuação do estilo afirmado pelo romance de 1881 para a crítica da época, os contos de Papéis avulsos assumem tom similar aos das Memórias póstumas.

A guerra russo-turca, antes um elemento que poderia ser considerado datado e escolhido única e exclusivamente para estabelecer uma aproximação com o leitor do jornal, agora funciona como evento em uma série que confirmaria a hipótese de que a corrupção humana, característica que Deus tinha intenção de eliminar com a criação da arca, persistiria através dos tempos. Agora, quatro anos depois do fim da guerra, há um afastamento do acontecimento por parte do público leitor, principalmente quando em comparação aos leitores d'O cruzeiro em 1878. A guerra russo-turca adquire, então, perspectiva metonímica, funcionando como a parte que representa o todo das guerras por território posteriores ao momento bíblico narrado.

\section{As “fases” de Machado: breves considerações}

A recepção primeira da obra nos jornais da época cristalizou muitos dos conceitos sobre a literatura machadiana que seriam reproduzidos nos anos vindouros. Além de reunirem Papéis avulsos a Memórias póstumas naquilo que seria a "segunda maneira” do autor, os resenhistas da obra classificam esse Machado como um filósofo e um humorista triste, pessimista, mais próximo de Schopenhauer, por exemplo. A crítica da Gazeta de Notícias, de autoria desconhecida, publicada no dia seguinte ao agradecimento à editora pelo envio da obra, é uma das primeiras a tratar das diferenças entre as "maneiras" da obra de Machado, além de tecer comentários sobre uma "impressão geral de aborrecimento e tédio" presentes nos textos (Gazeta de notícias, 1882, p. 1). Em sua crítica para a Gazeta da tarde - talvez a mais longa dentre o conjunto publicado pelos jornais 
da época, ocupando todo o espaço do folhetim -, Gama Roza (1882) 7 inicia com o comentário de que Papéis avulsos é uma continuação da maneira que surgiu a partir de Memórias póstumas. Assim como na crítica publicada pela Gazeta de notícias, o jornalista comenta que é difícil reconhecer "o poeta lírico e o escritor romântico de outrora" nos dois livros dessa segunda maneira, mais sombrios, mais pessimistas.

Diferentemente do que se possa acreditar, porém, a passagem de uma "fase" à outra não teria sido uma completa ruptura, como atestam alguns críticos. Os escritos em prosa que o artista carioca publicou durante os anos 1870, principalmente aqueles do final da década, já preparavam o leitor para o que viria a seguir com a impressão de Memórias póstumas. Para Alfredo Bosi,

(...) quem percorreu os contos e os romances da década de [18]70 está preparado para ver a resolução de um desequilíbrio. O vinho novo rompe um dia os odres velhos. À medida que cresce em Machado a suspeita de que o engano é necessidade, de que a aparência funciona universalmente como essência, não só na vida pública mas no segredo da alma, a sua narração se vê impelida a assumir uma perspectiva mais distanciada e, ao mesmo tempo, mais problemática, mais amante do contraste (BOSI, 2007, p. 84).

Sendo assim, em leitura teleológica, pode-se dizer que os romances e contos da chamada "primeira fase" da obra do autor preparam o terreno para o que viria a seguir, tanto para os leitores quanto para o próprio Machado, que, cada vez mais, passava a enxergar certas questões, sociais ou literárias, de forma diferente. A própria relação dos narradores com o leitor altera-se ao longo das obras do autor, como Guimarães procura abordar:

Os leitores figurados nos quatro primeiros romances estão longe de formar uma galeria homogênea. Inicialmente, a desconformidade com o gosto do público real resulta numa forte idealização do leitor implícito, que em grande medida aparece como negação do leitor empírico, cujo gosto o narrador está empenhado em reformar. Assim, quando os narradores de Ressureição e A Mão e a Luva se dirigem ao leitor, eles simultaneamente se referem ao leitor como ele é e como ele deve ou deveria ser para fruir um novo tipo de romance. Apesar dos diferentes graus de agressividade antirromântica, há nos dois romances um claro empenho do narrador em transformar o leitor, em apresentá-lo como ele deveria ser. Os dois livros seguintes, num certo nível mais conformados ao gosto e às expectativas do leitorado empírico, incorporam essas expectativas à

\footnotetext{
7 Possível assinatura de Francisco Luiz da Gama Roza, jornalista formado em medicina que foi presidente das províncias de Santa Catarina e da Paraíba.
} 
narrativa, seja por meio do enredo movimentado seja pelo tom mais apaziguado com que o narrador se dirige ao leitor. Disso resulta um leitor implícito menos idealizado, em relação ao qual os narradores de Helena e Iaiá Garcia parecem ter poucas expectativas de transformação, ao mesmo tempo em que o leitor se torna alvo da agressividade muda dos narradores, que sistematicamente frustram as expectativas sugeridas na superfície da narração. Agressividade muda que, como sabemos, será transformada em agressividade estridente com o narrador de Brás Cubas, o que também implicará mudanças substanciais na figuração do leitor (GUIMARÃES, 2004, p. 170).

Silviano Santiago é um dos primeiros a defender a ideia de que a obra de Machado de Assis seja analisada como um sistema, "um todo coerentemente organizado, (...) à medida que seus textos se sucedem cronologicamente certas estruturas primárias e primeiras se desarticulam e rearticulam sob forma de estruturas diferentes, mais complexas e mais sofisticadas" (SANTIAGO, 200o, p. 27). Sendo assim, seria possível encontrar sinais do Machado maduro em suas obras iniciais, mesmo que de forma sutil ou ainda um pouco tímida.

\section{Conclusão}

Os sentidos do conto, portanto, alteram-se na mudança de um suporte a outro. A inscrição de "Na arca”, em Papéis avulsos, torna o conteúdo do texto mais abrangente e geral do que sua publicação em $O$ cruzeiro. Se, no jornal, a contextualização histórica do conto com os leitores é mais forte do que a ideia de metonímia, no livro essa relação se inverte.

Machado parece perceber a importância do meio na produção de sentido de um texto. Nesse sentido, a supressão do proêmio de uma versão para outra parece também uma tentativa de tirar do texto os traços jornalísticos que ele trouxesse, assemelhandose em parte a um anúncio de um furo, de uma notícia.

Ao mesmo tempo, ao selecionar os periódicos em que primeiro publicava seus escritos, Machado tinha o cuidado de avaliar quais deles trariam consigo um protocolo de leitura que mais pudesse contribuir com os sentidos do conto em questão. No caso, O cruzeiro, com seu caráter pouco afeito aos preceitos da escola Realista, caiu como uma 
luva para o momento que Machado enfrentava em sua obra, experimentando novas formas de escrita, como é possível notar em outros dos textos ali publicados. Contudo, em 1882, ano da publicação de Papéis avulsos, parece que o autor já teria estabelecido um caminho que pretendia trilhar em sua obra, fazendo uma seleção apurada dos textos que nele se encaixariam.

Ainda que a passagem de Machado de Assis de uma "primeira maneira” para uma "fase madura" possa não ser abrupta como supunham seus contemporâneos, é possível observar, a partir da experimentação presente no conjunto de textos publicados n'O cruzeiro, que Machado procurava retrabalhar estruturas já presentes em sua obra, e "Na arca” seria, dentre eles, um dos principais expoentes dessas alterações.

\section{Referências}

ASSIS, Machado de. Papéis avulsos. Rio de Janeiro: Lombaerts \& Cia, 1882. . Literatura realista. O primo Basílio, romance do Sr. Eça de Queiroz, Porto, 1878. In: LEITE, Aluízio (Org.) et al. Obra completa de Machado de Assis. Rio de Janeiro: Nova Aguilar, vol. III, 2015. p. 1206- 1215.

. Um capuchino de Jerusalém remeteu-me pelo (...). O cruzeiro, Rio de janeiro, n. 133, 14 mai. 1878. p. 1.

BOSI, Alfredo. O enigma do olhar. 4ª ed. São Paulo: WMF Martins Fontes, 2007.

CHARTIER, Roger. Os desafios da escrita. São Paulo: Editora UNESP, 2002. . Inscrever e apagar. São Paulo: Editora UNESP, 2007.

CRESTANI, Jaison Luís. A materialidade da literatura. A inscrição do romance Iaiá Garcia no 'folhetim do Cruzeiro'. Machado de Assis em linha. Rio de Janeiro, v. 6, n. 12, p. 45-65, dez. 2013.

EGO. “O primo Basílio". O cruzeiro, Rio de Janeiro, n. 105, 16 abr. 1878. p. 3.

GLEDSON, J.; GRANJA, L. Introdução. In: Assis, Machado de. Notas semanais. Campinas-SP: Ed. UNICAMP, 2008.

GOMES, Eugenio. Machado de Assis: influências inglesas. São Paulo: Pallas, 1976. 
GUIMARÃES, Hélio de Seixas. Os leitores de Machado de Assis. São Paulo: Edusp; Nankin, 2004.

. Machado de Assis, o escritor que nos lê. São Paulo: Editora Unesp, 2017.

HALLEWELL, Laurence. O livro no Brasil: sua história. $3^{\underline{a}}$ ed. São Paulo: Edusp, 2012.

MEYER, Marlyse. "Voláteis e versáteis, de variedades e folhetins se fez a chronica".

Boletim bibliográfico biblioteca Mário de Andrade. São Paulo, v. 46, n. 1-4, jan.-dez.1985.

“PAPÉIS AVULSOS”. Gazeta de Notícias. Rio de Janeiro, n. 299, 27 out. 1882. p. 1.

REGO, Enylton de Sá. O calundu e a panaceia. Rio de Janeiro: Forense Universitária, 1989. ROUANET, Sérgio Paulo. Riso e melancolia. São Paulo: Companhia das Letras, 2007.

ROZA, Gama. Os Papéis avulsos por Machado de Assis. Gazeta da tarde, Rio de Janeiro, 2 nov. 1882. p. 1.

SANTIAGO, Silviano. Retórica da verossimilhança. In: . Uma literatura nos trópicos: ensaios sobre dependência cultural. Rio de Janeiro: Rocco, 2ª ed., 200o. p. 2746.

SILVA, Márlio Barcellos Pereira da. Procedimentos paródicos e distanciamento irônico em Papéis avulsos, de Machado de Assis. Dissertação (Mestrado em Literatura Brasileira) FFLCH-USP, São Paulo, 2009.

TEIXEIRA, Ivan. O altar $\mathcal{E}$ o trono. Cotia, SP: Ateliê Editorial/ Campinas, SP: Editora da Unicamp, 2010.

Pássaro sem asas ou morte de todos os deuses. In: ASSIS, Machado de. Papéis Avulsos. São Paulo: Martins Fontes, 2005. p. LII.

Recebido em 23/o6/2020.

Aprovado em 17/o8/2020. 